\title{
THE SUCCESSFUL INTERNATIONALIZATION OF INTESA SANPAOLO BANK IN CENTRAL AND EASTERN EUROPE: ACQUISITIONS, INSIDERSHIP AND THE UPPSALA MODEL
}

\section{Valdemarin, $\mathbf{S}$.}

The study of internationalization processes of multinational enterprises and its evolution is one of the most important topics in the domain of international business. According to the Uppsala model and the business network view, being an insider in local networks is a fundamental issue for service companies such as banking Groups because of their strong intangible dimension. That's why VUB Bank is an extraordinary bank. It has a little office in Prague, the only one in Czech Republic, and, at the same time, owns 233 branches in Slovakia. But this bank is a subsidiary of Intesa Sanpaolo, the biggest Italian banking Group, one of the leaders in the European market. Starting from this empirical observation, and using an inductive methodology, this paper will try to explain how the Intesa Sanpaolo Group successfully created a business network in Slovakia, its first market by total assets in Central and Eastern Europe. Our study shows that banking Groups can overcome the liability of outsidership through a progressive commitment and a "local-passport strategy" based on the acquisition of existing companies.

Keywords: Internationalization; Uppsala Model; Mergers and Acquisitions; Networks; Central and Eastern Europe

JEL classification: F23, G21

\section{Introduction}

Our interest in studying how a multinational corporation (MNC) as Intesa Sanpaolo internationalizes in Central and Eastern Europe arises from three observations. The first one refers to theory. Banks are service companies, and service companies always rely in intangible dimension more than industrial Groups. As Professor Collin explains: "One of the specifics of services is their strong intangible dimension. Service MNCs cannot remain isolated. They need partners, especially in an international context, and thus from international alliances and/or networks." (Collin, 2012, p. 204). More than this, European banking Groups were forced to adapt to a shifting world in a context of harmonized regulation (Basel 1 and 2), financial crisis and never-ending debates between Pro-Europeans and Euro-skeptics (Ionescu, 2014). From those observations it seems that the success of service companies like banks is deeply tied to its capacity to reduce uncertainty by using networking strategy and leveraging on relationships with local actors.

Another theoretical consideration concerns the development of banks and insurance companies in Central and Eastern Europe. We share the idea that "Cross-border integration is the central management issue for banks that expand internationally, and this is especially true in Central and Eastern Europe, where the pace of internationalization through mergers and acquisitions has been rapid." (Ambos, Schlegelmilch, Ambos, \& Brenner, 2009, p. 633). Central and Eastern Europe represents an attractive market for foreign direct investments (FDI) from other European countries (Valdemarin, 2015) and mergers and acquisitions seems to develop as quick way to enter specific markets such 
as Czech Republic (Thivant \& Machková, 2017). Furthermore, it seems that brownfield investments through (M\&A) represent a growing trend (Martin \& Shalev, 2017) with the emergence of many serial acquirers (Ismail, 2008) between multinational companies.

The third observation is empirical and concerns VUB Bank (the original name is Všeobecná Úverová Banka) that has only a little office near to the center of Prague, in Czech Republic, and at the same time is the second bank in Slovakia with 233 branches and about 1.600.000 clients (Intesa Sanpaolo, 2016, p. 9). VUB Bank is a member of Intesa Sanpaolo, a banking Group that is growing faster and faster in Central and Eastern Europe (Bottiglia, 2009, p. 619).

So there is at the same time a theoretical and managerial interest on the analysis of VUB Bank evolution in Eastern European Countries like Slovakia and Czech Republic. That's why our research question is: "How the Intesa Sanpaolo banking Group created a network in Slovakia?"

To answer this question we will use the business network theoretical framework (Forsgren, Holm, \& Johanson, 2006), and more specifically the Uppsala model (Vahlne \& Johanson, 2013). Then we will contextualize our analysis, explaining the internationalization strategy of Intesa Sanpaolo Bank in Central and Eastern Europe. According to previous studies on internationalization of banking Groups (Kulczycki, 2006; Parada, Alemany, \& Planellas, 2009), it seems that there are different obstacles to enter new markets that the business network view can explain by the concept of "liability of outsidership" (Johanson \& Vahlne, 2009). Moving from theory we will try to understand how Intesa Sanpaolo overcame this liability by creating a business network in Slovakia by performing a longitudinal analysis on a single case study (Ghauri \& Grønhaug, 2005; Siggelkow, 2007).

So, the first part of the paper introduces the theoretical framework and the empirical contextualization. In the second part we will focus on methodology. In the third one we will show how Intesa Sanpaolo successfully integrated the Slovakian market through VUB Bank.

\section{Theoretical Framework: The Business Network View and the Uppsala model}

Our analysis attempts to explain how the Intesa Sanpaolo Group created a network of 233 branches in Slovakia moving from the business network theory and, more specifically, from the Uppsala model. Actually there are many studies on the organizational structure of banking Groups in Central and Eastern Europe (Ambos et al., 2009), on their strategy (Kulczycki, 2006; Lopes, Hoffmann, \& Amal, 2017; Ul-haq \& Howcroft, 2007) and on the local environment (Bruggink, Karsten, \& de Meijer, 2012; Parada et al., 2009). It's wholly recognized that the network represents a key issue for those Groups (Collin, 2012). Nevertheless, it seems that there is a gap in literature analyzing internationalization of banking Groups through a business network view. That's why our theoretical framework is based on the business network view of the multinational corporation and the Uppsala Model, as they allow us to understand the evolution of Intesa Sanpaolo through VUB Bank in Slovakia.

Multinational corporations (MNC, also called multinational enterprises, MNE), in the business network view, can be defined as networks within networks (Dicken, 2015). In fact, the corporation itself can be considered as a network, because it contains some nodes (headquarters, subsidiaries, actors) interconnected by ties or relationships. At the same time, the multinational corporation can be considered also as a part of an external 
network composed by other companies, states, organizations and actors in general. So the network has both an intra-organizational and inter-organizational dimension. Those dimensions are interconnected, mostly because the internal hubs always interact with the external network (Vahlne \& Johanson, 2013).

The Uppsala model, starting from its 2009 version and, more completely in its 2013 and 2017 version, explains that networks are an essential element of the internationalization strategy. In fact, the original model stated that MNCs that try to internationalize have to overcome a liability of foreignness (Johanson \& Vahlne, 1977). This liability deals with different socio-economic factors. The enterprise needs to face a new environment, characterized by cultural and psychic barriers and is affected by a liability of foreignness face to local companies. That's why, in the Uppsala model of 1977, the internationalization process consists in a progressive path, moving from countries with a low level of psychic and cultural distance to other countries where liability of foreignness is stronger.

The new model moves from the concept of liability of foreignness to the concept of liability of outsidership (Blankenburg Holm, Johanson, \& Kao, 2015; Johanson \& Vahlne, 2009). As authors say: "A lack of institutional market knowledge - that is, lack of knowledge about language, laws, and rules - has to do with factors related to psychic distance, and to the liability of foreignness. Lack of business market knowledge is related to a firm's business environment that, according to the business network view, consists of the firms with which it is doing business, or trying to do business, and the relationships between firms in this environment. The lack of such market-specific business knowledge constitutes the liability of outsidership." (Johanson \& Vahlne, 2009, p. 1416).

The problem that the firm needs to face when it tries to internationalize does not depends only on cultural proximity but it's related to the fact that the firm may be an outsider of the local networks. To overcome the liability of outsidership the MNC needs to build networks or work in order to enter existing ones (Almodóvar \& Rugman, 2015). The new model gives to the network a central role. The position in the inter and intra-organizational network and the network power, that are defined as dynamic capabilities, are closely related to the processes of learning, creating and trust building of the firm, and to the capability of recognize and exploit new opportunities (Vahlne \& Johanson, 2013).

In recent years, the Uppsala model began one of the main frameworks in international business and in the end of 2017 the Journal of International Business Studies published a special issues focusing on this paradigm. In their most recent article, Vahlne and Johanson (2017) the development of the model from 1977, offering a new framework explaining the evolution of multinational enterprises (Coviello, Kano, \& Liesch, 2017; Santangelo \& Meyer, 2017). As authors say: "The updated, augmented model explains MBE evolution in general, not only characteristics of the internationalization process in a narrow sense." (Vahlne \& Johanson, 2017, p. 1087).

In a global shifting context (Mayrhofer \& Urban, 2011) a commitment decision is deeply tied to a reconfiguration of the activities and a change of coordination (Vahlne $\&$ Johanson, 2013). This decision implies the activation of organizational processes, also called knowledge development processes (processes that firms put in place to face the external environment) like learning, creating and trust-building (Johanson \& Vahlne, 2009; Vahlne \& Jonsson, 2017) that are useful to overcome the liability of outsidership. Those elements, which are part of the change aspects, are connected with state aspects. The firm learns how to create networks or how to enter in an existing one, it 
builds internal and external trust and create ties. The result is an improvement in network position and network power (Vahlne \& Johanson, 2013) that can be named, in a general sense, "Commitments/Performance" (Vahlne \& Johanson, 2017). All those elements deal with the evolution of firm's operational and dynamic capabilities like opportunity development, internationalization and networking skills. In this way the MNC build its own network position, both at an inter-organizational and at an intra-organizational level, and manage its network power (Vahlne \& Johanson, 2013).

\section{Figure 1 | The Uppsala internationalization and evolution process}

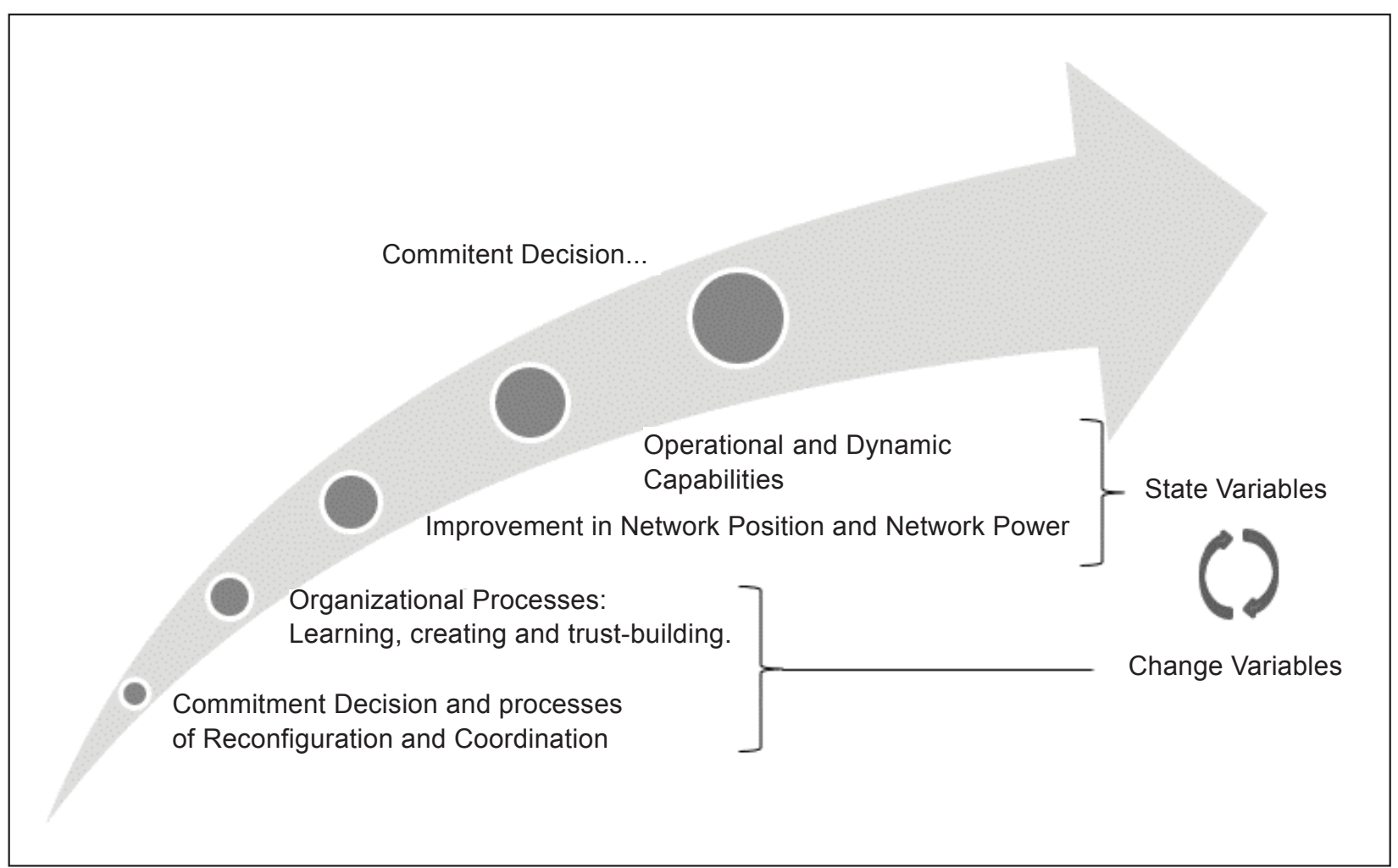

Source : Elaboration of the author based on Vahlne \& Johanson $(2013,2017)$

The Uppsala model is a dynamic model based on business network view that was conceived to answer the question "How does the MNE evolve?" (Vahlne \& Johanson, 2013, p. 191). As Figure 1 shows, the model considers state and change aspects of the firm as interconnected (Johanson \& Vahlne, 1977) and it's conceived as a sort of "virtuous circle". Concerning the internationalization process of leading banking Groups, which has been also studied in recent years and, it seems that they follow five main internationalization paths (Lopes et al., 2017): opportunity seeking, greenfield investments, gradual investments with subsequent acquisition, acquisition of market leaders, multiple acquisitions with subsequent mergers.

In fact, according to the Uppsala model, every kind of entry mode represents a commitment decision with a reconfiguration of resource allocation and change of coordination, activating organizational processes in order to improve capabilities, performance and resulting in additional commitments. In the same way opportunity seeking corresponds to an exploration issue (Vahlne \& Johanson, 2017; Vahlne \& Jonsson, 2017) that is fully integrated in commitment decision and evolution processes. 
As the Uppsala model and the business network view gives us an idea of how a firm evolves through networks (Coviello et al., 2017) and offers a dynamic approach that allows us to better understand interconnected systems, considering that internationalization path can be interpreted as network issues relying on increasing commitments. We rely on those frameworks as evolutionary issues seems to be relevant for the study of our case, looking at the evolution of Intesa Sanpaolo Bank in Central Europe.

\section{Contextualization: Intesa Sanpaolo Bank}

From the $1^{\text {st }}$ of December 2006 Intesa Sanpaolo is the Italian leading banking Group and is presence all around the world is growing fast (Intesa Sanpaolo, 2017). The Group is the result of the successful merger between Banca Intesa and Sanpaolo IMI, two of the biggest Italians players in banking sector (Bottiglia, 2009). Nowadays Intesa Sanpaolo has a worldwide presence and its international subsidiary division deserves 7.5 million customers and owns 1055 branches outside Italy, with a growing market presence in Central-Eastern Europe and North Africa (Intesa Sanpaolo, 2017, p. 22). The following picture shows the presence of Intesa Sanpaolo in Central-Eastern Europe by number of branches, excluding Czech Republic, where the Group owns only one office as a subsidiary of VUB Bank in Slovakia.

\section{Figure 2 | The number of branches of Intesa Sanpaolo by Country in Central and Eastern Europe}

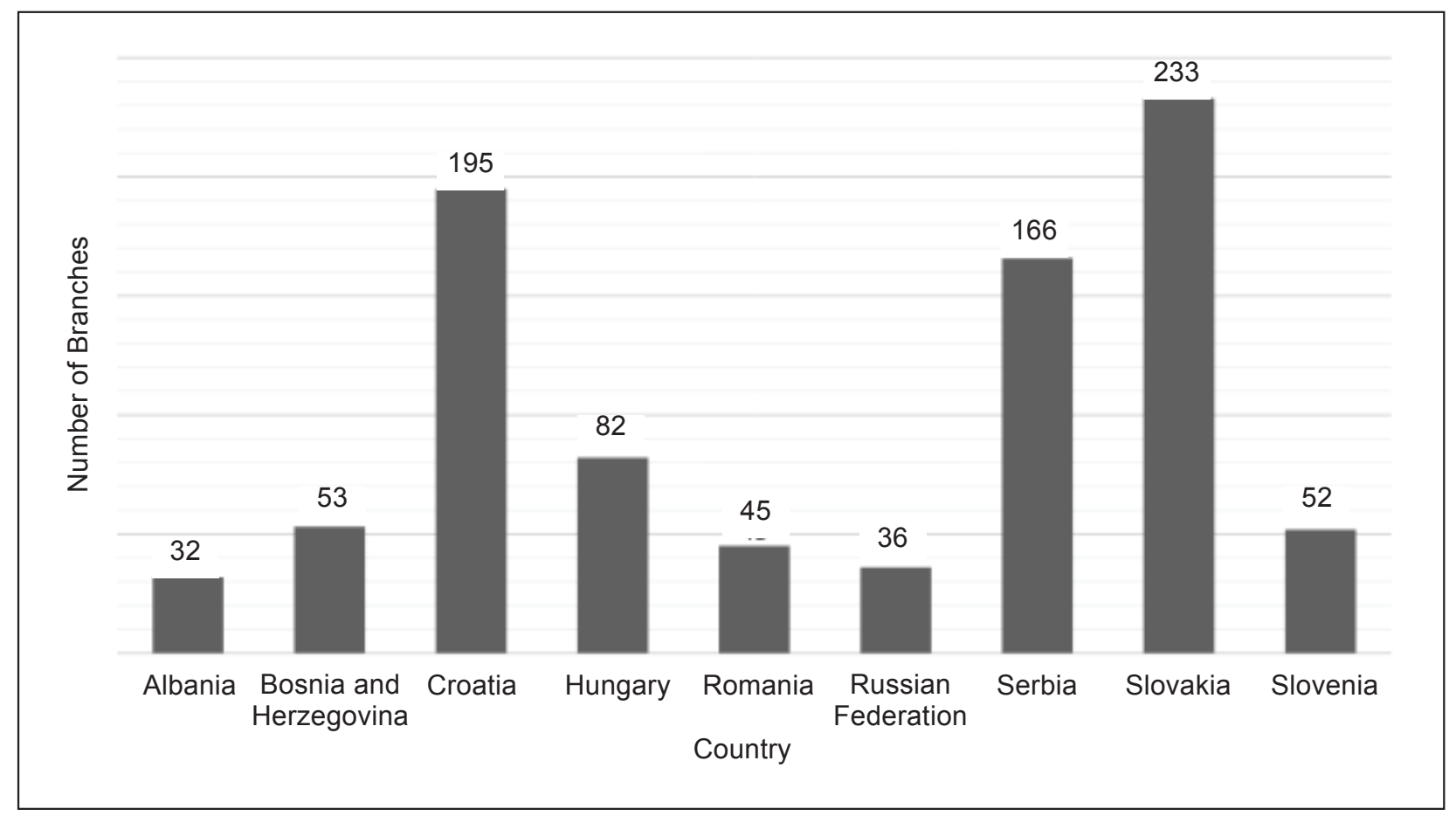

Source : Elaboration of the author based on Intesa Sanpaolo (2016, p. 9)

As we can easily see, Slovakia, Croatia and Serbia are the principal markets for number of branches. In those markets, the Group is between the top three players. In order to better understand the market position of Intesa Sanpaolo in Central and Eastern Europe, we can look at Table 1 that lists the subsidiaries of the Group by total assets, ranking and number of customers. 
Table 1 | The international subsidiary banking division of Intesa Sanpaolo in Central and Eastern Europe

\begin{tabular}{|l|c|c|c|}
\hline \multicolumn{1}{|c|}{ Country } & $\begin{array}{c}\text { Total Assets } \\
\text { (Euro mil) }\end{array}$ & $\begin{array}{c}\text { Ranking (by Total } \\
\text { Assets) }\end{array}$ & $\begin{array}{c}\text { Number of Customers } \\
\text { (Thousand) }\end{array}$ \\
\hline Albania & 1,126 & 4 & 188 \\
\hline Bosnia and Herzegovina & 889 & 7 & 163 \\
\hline Croatia & 9,864 & 2 & 1,653 \\
\hline Hungary & 5,242 & 7 & 435 \\
\hline Romania & 900 & n.a. & 69 \\
\hline Russian Federation & 859 & n.a. & 258 \\
\hline Serbia & 4,525 & 1 & 1,412 \\
\hline Slovakia & 14,607 & 2 & 1,625 \\
\hline Slovenia & 2,322 & 7 & 191 \\
\hline
\end{tabular}

Source : Elaboration of the author based on Intesa Sanpaolo (2017, pp. 24-25)

\section{Methods}

In order to answer our research question we performed a qualitative analysis (Ghauri \& Grønhaug, 2005) based on a single case study (Eisenhardt \& Graebner, 2007; Yin, 2009). The object of our research represents a successful case (Siggelkow, 2007) of internationalization through mergers, as VUB Bank is the second player on Slovakian banking market in 2017 (Intesa Sanpaolo, 2017). Case studies, and even more single case studies, are mainly based on an in-deep analysis (Cuervo-Cazurra, Andersson, Brannen, Nielsen, \& Rebecca Reuber, 2016), helping scholars to explore new trends (Yin, 2009) and find alternative explanation (Cuervo-Cazurra et al., 2016), following different path to explain complex phenomena (Bertalanffy, 1968). In this context a single case study is representative (Siggelkow, 2007) and may be the object of analytic generalization (Yin, 2010).

Our analysis is mainly based on official documents and communications published by Intesa Sanpaolo and VUB Bank like interviews in financial reports, shareholders' meetings presentations and annual reports. We collected also data from Eikon, the main information software owned by Thomson Reuters (2017), mainly from "Events", "Deal list M\&A" and "M\&A Tearsheet" sections until February 2017. Additional secondary data have been collected from publication about Intesa Sanpaolo and VUB Bank and international publications.

\section{Results}

The internationalization of Intesa Sanpaolo in Slovakia began in 2001, as an initiative of Intesa BCI (VUB Bank, 2002), with the acquisition of the government stake of Všeobecná Úverová Banka (McDonald \& Keasey, 2003; VUB Bank, 2017) the state-owned bank that was seeking a buyer for privatization from 1994 (Eikon, 2017). Before the acquisition by the Italian Group, the International Finance Corporation (IFC), and the 
European Bank of Reconstruction and Development (EBRD), acquired a 25.89\% stake of VUB in 1996 to help the early phase of the privatization (Eikon, 2017; Hardt \& Kaufman, 2016). The decision of acquiring VUB - acquired with the Government stake and by planning to buy the remaining interest from IFC and EBRD - can be seen as a commitment decision (Vahlne \& Johanson, 2013) of Intesa BCI to enter the Slovakian market. As Luigi Carnelli, Chairman of the Supervisory Board of VUB in 2002, said: "For Gruppo Intesa, the commitment to Slovakia is an integral part of a long-term strategy of building a financial Group of European significance." (VUB Bank, 2002, p. 6). This commitment decision represented the first step to reduce the liability of outsidership (Johanson \& Vahlne, 2009) in the local market, as the Group was acquired thanks to an agreement with the local government for a price of 379 million Dollars (Eikon, 2017).

In this process of entering the new market, the Italian bank set up organizational processes merged with a "local-passport strategy" (Dicken, 2015). Dealing with the new market asked for organizational learning in order to create new solutions and building trust both in the internal and the external network. We find those issues in the words of Luigi Carnelli: "Branch network restructuring, improvement of customer care and product quality are bearing its fruit in the form of higher revenues and more loyal customers. [...] The current banking practice is knowledge-intensive. Therefore, a decisive factor for success is human capital and the bank's effort to attract and retain talented employees will certainly be rewarded." (VUB Bank, 2002, p. 6). The same concept is enhanced by Tomas Spurny, Chairman of the Management Board and Chief Executive Officer of VUB in 2002: "There is only one way leading to this goal: maximum leveraging on the bank's human capital and on the know-how of the international financial Group so as to exceed our clients' expectations." (VUB Bank, 2002, p. 7).

Those actions resulted in an improvement of network position and network power both at the inter- and intra-organizational level (Vahlne \& Johanson, 2013), not only in term of results, with a growth of operating revenue by $20 \%$ and an improvement of consolidated net profit by nearly $60 \%$, but also in terms of customers and presence on the local market. In order to grow up its accessibility to retail customers, in between 2001 and 2002 VUB installed 59 news ATMs, issued 95,274 new credit cards, more than doubling the number of cards issued on the previous year, maintained the leadership on mortgages and customer loans (VUB Bank, 2002).

As a consequence of the learning process (Johanson \& Vahlne, 2009), VUB strongly improved operational capabilities by updating processes, improving quality standards and modernizing infrastructures (VUB Bank, 2017). More than this, Gruppo Intesa helped VUB in developing new products and a new approach to customer. In the same way, the bank enhanced its dynamic capabilities (Almodóvar \& Rugman, 2015). If we simply rely on the number of transactions in order to evaluate the networking capability, then 2002 is marked by a significant improvement on the number of transactions by phone and internet banking (VUB Bank, 2002), as the following picture shows.

At the Intesa BCI level the first steps of internationalization in Slovakian market helped the improvement of opportunity development capability, internationalization capability and networking capability (Vahlne \& Johanson, 2013, 2017) in order to become an "Italian leader with a European scale" (Intesa Sanpaolo, 2017). The positive results encouraged the commitment decision of Intesa Sanpaolo on the Slovakian market, following the local-passport strategy (Dicken, 2015) and setting up a wave of acquisitions in order to enlarge their network and evolve in the local market. 


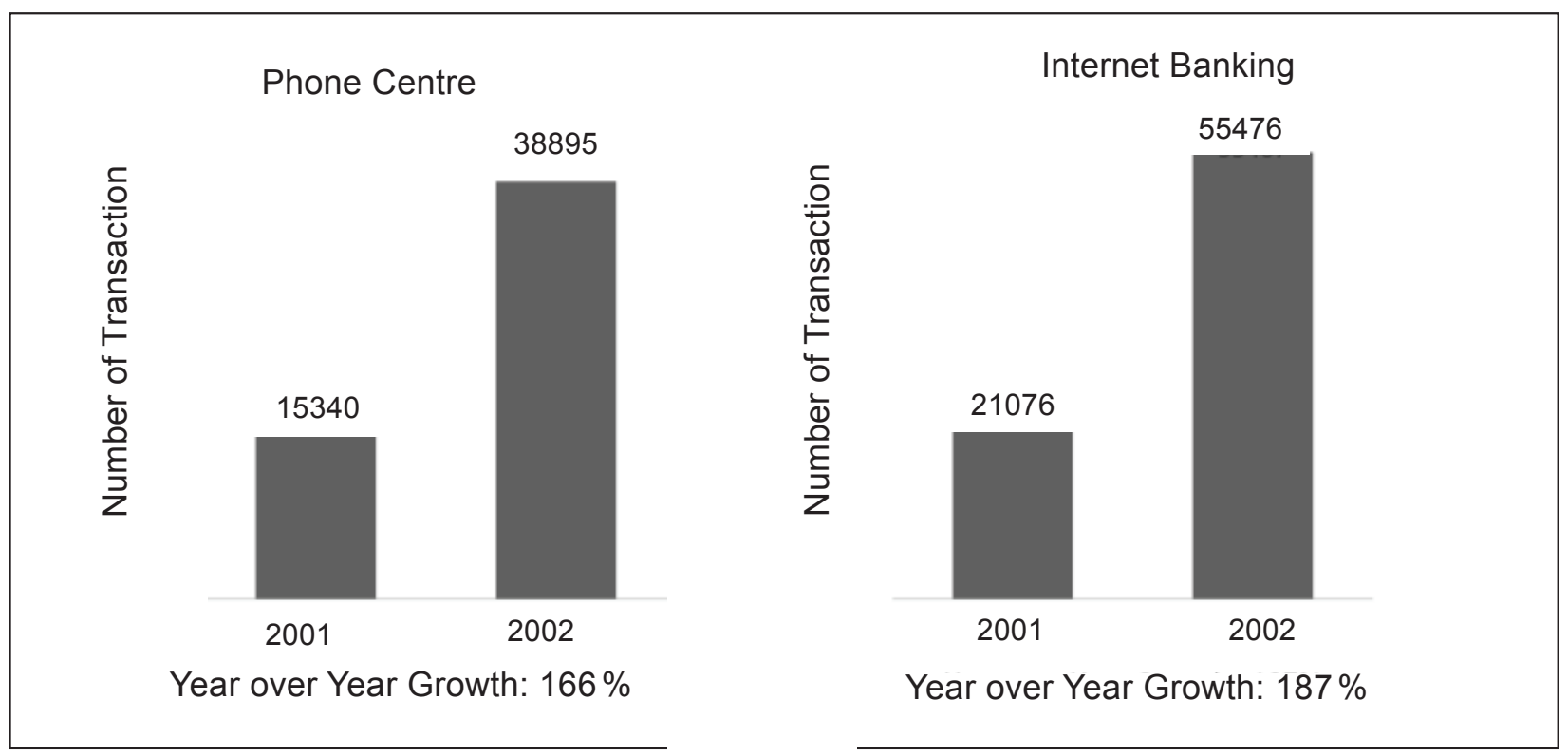

Source : Adapted by the author from VUB Bank $(2002$, p. 16)

The 16/04/2004 VUB Bank, in the behalf of Banca Intesa, acquired a provider of credit cards, Kiska, with the purpose to grow up its presence on the Slovakian market (Eikon, 2017). This acquisition represents a reinforcement of the commitment decision motivated by the increasing demand of credit cards on the local market. The following year, starting from January 2005, VUB Bank strengthened its commitment by acquiring Slovenská Požičovňa, Slovenské Kreditné Karty, Quatro As, Q-Car and TatraCredit, providers of financing services and credit and debit cards (Eikon, 2017). This new wave of acquisition represents a natural path on the process of assets reconfiguration but is also a strategic tool as György Surányi, Chairman of the Supervisory Board of VUB in 2005 explains: "Strategy focused on value creation in a systematic and determined way: from post privatization restructuring and transformation to sustainable and healthy growth, accompanied by strict cost discipline, sound risk management practices, and continuous investments into innovation. Strategy, that has turned the bank into a modern, dynamic, and, most importantly, client-oriented financial institution." (VUB Bank, 2005, p. 2). In this context, VUB owned in 2005 one-fourth of the ATMs in Slovakia, increased from $14 \%$ to $15 \%$ its share on credit markets and improved by $85 \%$ the internet banking and by $127 \%$ the new home banking on a Year over Year base (VUB Bank, 2005). The network expanded as the number of branches did: from 2002 to 2005 VUB grew up from 141 branches to 154 branches (VUB Bank, 2002, 2005).

After the merger between Banca Intesa and San Paolo IMI in December 2006, the commitment on the Slovakian market was reinforced. As György Surányi said: "For Banca Intesa, the year 2006 has been very important, as we merged with our next closest Italian competitor, Gruppo Sanpaolo IMI into a new entity, Intesa Sanpaolo. [...] I would like to reaffirm the strategic commitment of Banca Intesa and indeed Intesa Sanpaolo to the fast-growing Central and Eastern European Markets, commitment in which VUB plays an integral part." (VUB Bank, 2006, p. 2)

In recent years the commitment of VUB Bank on the Slovakian market was reinforced and now this is the first market in Central and Eastern Europe for Intesa Sanpaolo 
by total assets and number of branches (Intesa Sanpaolo, 2017). In 2007, in order to strengthen its position in leasing industry, VUB Bank acquired 70\% of BOF, a Slovakian provider of leasing services, for 16.595 million dollars (Eikon, 2017). BOF was renamed VUB Leasing and between 2007 and 2008 boosted by $20 \%$ the position of VUB Bank in the leasing market on a year over year basis (VUB Bank, 2008, p. 132). This acquisition was completed in 2010, when the bank acquired the remaining $30 \%$ stake on VUB Leasing to boost their market share on car-leasing services (Eikon, 2017).

As we can easily see, Intesa Sanpaolo's internationalization strategy in Slovakia was based on waves of M\&As in order to gradually offer a wider range of services to its clients. Previous studies have shown the importance of the network for service companies like banks (Collin, 2006, 2012) and that the internationalization process of those companies is usually linked to strategic alliances and M\&As (Kulczycki, 2006; Parada et al., 2009; Ul-haq \& Howcroft, 2007). Our case study is a good example of internationalization following the Uppsala Model and using M\&As as strategic tools to accelerate the integration in a new market.

Thus we think that for Intesa Sanpaolo, M\&As can be seen as an effective commitment decision and the Uppsala Model, as presented in Figure 4, gives a good representation of the processes that were set up and the internationalization of the Italian banking Group through waves of acquisitions.

Figure 4 | The internationalization process of Intesa Sanpaolo through M\&As

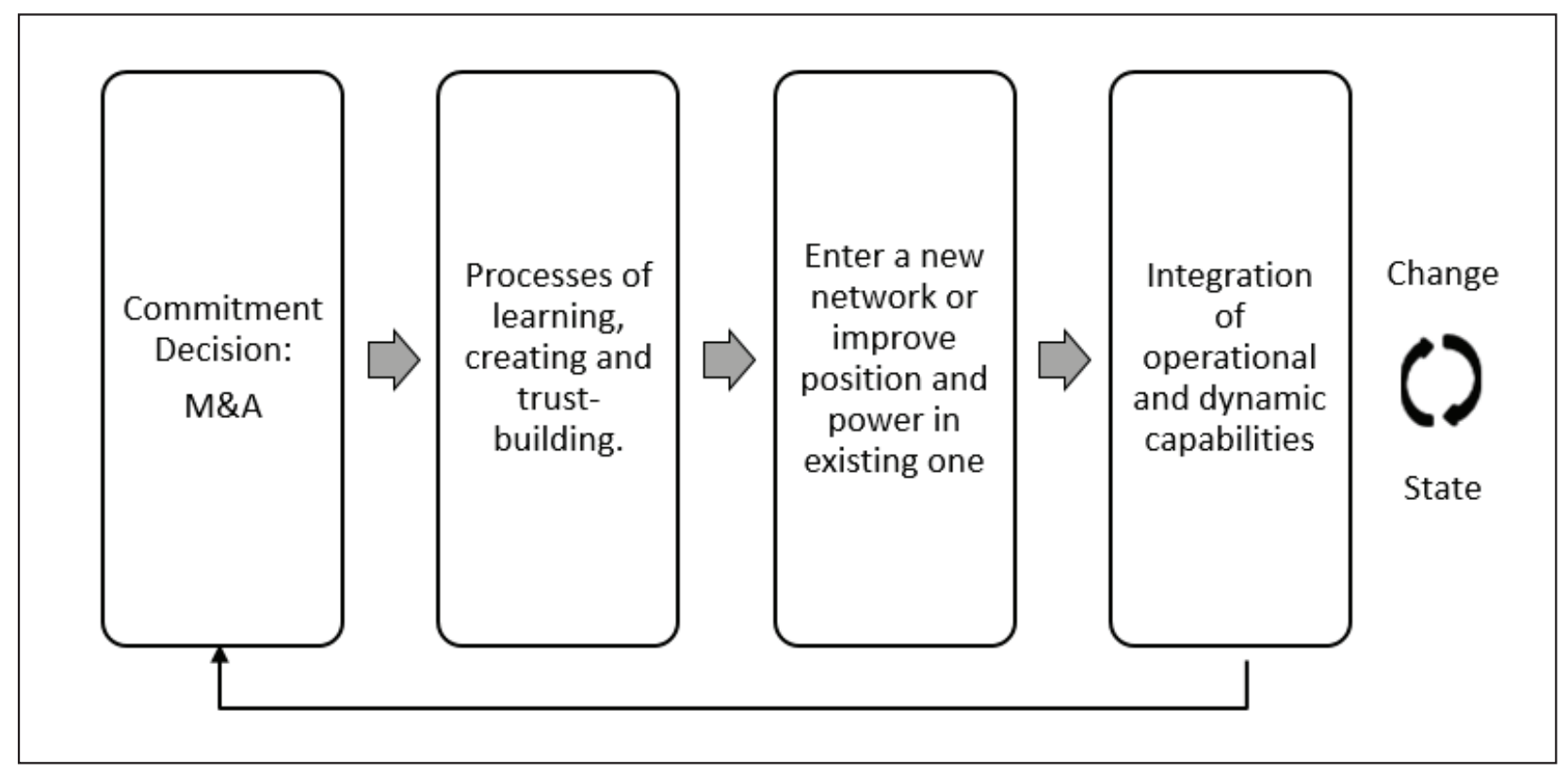

The liability of outsidership is reduced by a virtuous circle implying a progressive reinforcement of the commitment decision, a continuous change of coordination reshaping the organization following acquisitions. This process is based on the attitude of learning from the local environment for Intesa Sanpaolo and from the Headquarters for VUB Bank, creating new solutions and building trust inside and outside the Group. The network position and the network power are consequently reinforced just as the operational and dynamic capabilities. New M\&As, rooted in a stronger commitment in Slovakia, helped Intesa Sanpaolo to reinforce the position of VUB Bank in the local market, for 
example with the acquisition of credit cards providers, or to enter new market sectors like car-leasing services. The proof of the success of VUB Bank on the Slovakian network is the growth of the number of branches from 141 in 2002 to 233 in 2017 (Intesa Sanpaolo, 2017; VUB Bank, 2002).

\section{Conclusion}

The research we performed helped us in understanding how an international banking Group like Intesa Sanpaolo internationalizes in Central and Eastern Europe. The case study of VUB Bank reveals that, as proposed by the Uppsala model, the liability of outsidership can be reduced by integrating the local network and shows that acquisition strategies are usually performed in order to put in place a local-passport strategy. It seems that integrating an existing network through M\&As is more simple than creating a new one. Studies testing the link between the business network view and the literature on acquisitions are welcome as they may help scholars and managers to face the growing trend of M\&As.

This paper offers an original point of view of the internationalization of banking sector applying an established international business model that was originally conceived for industrial and production firms. Further studies may also enlarge the scope of the Uppsala model by testing it on other banks or service companies and it may also be interesting to perform new comparative studies focused on differences between the internationalization process of service companies and manufacturing ones.

Another interesting point of this article may follow the consideration that a new commitment decision can quickly develop new issues on local markets. As we previously said, VUB Bank owns an office in Czech Republic too. Maybe this study can help to understand what are the key issues a banking Group sets up in order to succeed in a new market. The subsidiary in Czech Republic may quickly became an entry point for Intesa Sanpaolo in the local market and rise the interest of scholars and managers.

As we said, the Uppsala model is conceived as a virtuous circle and an improving process (Johanson \& Vahlne, 1977). That's why, 2017 is not the end of the internationalization of Intesa Sanpaolo in Slovakia, but represents one phase of a process that may lead VUB Bank to fulfill its commitment to become the leader in the Slovakian market.

\section{References}

Almodóvar, P., \& Rugman, A. M. (2015). Testing the revisited Uppsala model: does insidership improve international performance? International Marketing Review, 32(6), 686-712.

Ambos, T. C., Schlegelmilch, B. B., Ambos, B., \& Brenner, B. (2009). Evolution of Organisational Structure and Capabilities in Internationalising Banks: The CEE Operations of UniCredit's Vienna Office. Long Range Planning, 42(5-6), 633-653.

Bertalanffy, L. von. (1968). General System Theory. New York: George Braziller.

Blankenburg Holm, D., Johanson, M., \& Kao, P. (2015). From outsider to insider: Opportunity development in foreign market networks. Journal of International Entrepreneurship, 13(3), 337-359.

Bottiglia, R. (2009). I grandi gruppi bancari: formazione, sviluppo e crisi. Giuffrè Editore.

Bruggink, D., Karsten, P., \& de Meijer, C. (2012). The European cards environment and ISO 20022. Journal of Payments Strategy \& Systems, 6(1), 80-99. 
Collin, P. M. (2006). Bâtir un réseau mondial de services: L'exemple de la monnaie électronique. Paris: Editions L'Harmattan.

Collin, P. M. (2012). The construction of networks by MNCs: an analysis of the banking sector. In U. Mayrhofer (Ed.), Management of Multinational Companies: A French Perspective (pp. 204-220). New York: Palgrave Macmillan.

Coviello, N., Kano, L., \& Liesch, P. (2017). Adapting the Uppsala model to a modern world: Macro-context and microfoundations. Journal of International Business Studies, 48(9), 1151-1164.

Cuervo-Cazurra, A., Andersson, U., Brannen, M., Nielsen, B., \& Rebecca Reuber, A. (2016). From the Editors: Can I trust your findings? Ruling out alternative explanations in international business research. Journal of International Business Studies, 47(8), 881-897.

Dicken, P. (2015). Global Shift: Mapping the Changing Contours of the World Economy (Seventh Edition). London: Sage Publications.

Eikon (2017). Thomson Reuters [Database].

Eisenhardt, K. M., \& Graebner, M. E. (2007). Theory Building from Cases: Opportunities and Challenges. Academy of Management Journal, 50(1), 25-32.

Forsgren, M., Holm, U., \& Johanson, J. (2006). Managing the Embedded Multinational: A Business Network View. Chaltenham: Edward Elgar.

Ghauri, P. N., \& Grønhaug, K. (2005). Research Methods in Business Studies: A Practical Guide. London: Pearson Education.

Hardt, J. P., \& Kaufman, R. F. (2016). East-Central European Economies in Transition. London: Routledge.

Intesa Sanpaolo. (2016). 2016 Intesa Sanpaolo Annual Report (Annual report) (p. 694). Turin. Retrieved Retrieved January 12, 2018, from http://www.group.intesasanpaolo.com/ scriptlsir0/si09/contentData/view/content-ref?id=CNT-05-00000004D7191

Intesa Sanpaolo (2017). Italian Leader with a European Scale. Milano. Retrieved January 15, 2018, from http://www.group.intesasanpaolo.com/scriptlsir0/si09/contentData/view/ Brochure_istituz_en.pdf?id=CNT-04-00000000418CF\&ct=application/pdf

Ionescu, A. (2014). The European Banking System. Track Record And Achievement. Global Economic Observer, 2(2), 93-102.

Ismail, A. (2008). Which acquirers gain more, single or multiple? Recent evidence from the USA market. Global Finance Journal, 19(1), 72-84.

Johanson, J., \& Vahlne, J.-E. (1977). The Internationalization Process of the Firm-A Model of Knowledge Development and Increasing Foreign Market Commitments. Journal of International Business Studies, 8(1), 23-32.

Johanson, J., \& Vahlne, J.-E. (2009). The Uppsala internationalization process model revisited: From liability of foreignness to liability of outsidership. Journal of International Business Studies, 40(9), 1411-1431.

Kulczycki, M. (2006). Making cross-border retail finance a reality case study: Deutsche Bank PBC S.A. in Poland. Journal of Financial Services Marketing, 11(2), 157-165.

Lopes, A. L. A., Hoffmann, V. E., \& Amal, M. (2017). Internationalization Strategies Underlying the Performance of Foreign Banks in Latin American Markets. Latin American Business Review, $18(2), 91-120$.

Martin, X., \& Shalev, R. (2017). Target Firm-Specific Information and Acquisition Efficiency. Management Science, 63(3), 672-690.

Mayrhofer, U., \& Urban, S. (2011). Management international. Des pratiques en mutation. Paris: Pearson Education. 
McDonald, O., \& Keasey, K. (2003). The Future of Retail Banking in Europe: A View from the Top. Chichester: John Wiley \& Sons.

Parada, P., Alemany, L., \& Planellas, M. (2009). The Internationalisation of Retail Banking: Banco Santander's Journey towards Globalisation. Long Range Planning, 42(5-6), 654-677.

Santangelo, G., \& Meyer, K. (2017). Internationalization as an evolutionary process. Journal of International Business Studies, 48(9), 1114-1130.

Siggelkow, N. (2007). Persuasion with Case Studies. Academy of Management Journal, 50(1), 20-24.

Thivant, E., \& Machková, H. (2017). An Analysis of French Mergers and Acquisitions in Different Sectors of the Czech Economy. Central European Business Review, 6(1), 48-60.

Ul-haq, R., \& Howcroft, B. (2007). An examination of strategic alliances and the origins of international banking in Europe. International Journal of Service Industry Management, $18(2), 120-139$.

Vahlne, J.-E., \& Johanson, J. (2013). The Uppsala model on evolution of the multinational business enterprise - from internalization to coordination of networks. International Marketing Review, 30(3), 189-210.

Vahlne, J.-E., \& Johanson, J. (2017). From internationalization to evolution: The Uppsala model at 40 years. Journal of International Business Studies, 48(9), 1087-1102.

Vahlne, J.-E., \& Jonsson, A. (2017). Ambidexterity as a dynamic capability in the globalization of the multinational business enterprise (MBE): Case studies of $A B$ Volvo and IKEA. International Business Review, 26(1), 57-70.

Valdemarin, S. (2015). Analysis Regarding the Growing Presence of Italian Firms in Romania. Central European Business Review, 4(4), 58-70. https://doi.org/10.18267/j.cebr.138

VUB Bank (2002). 2002 VUB Annual Report (Annual report) (p. 143). Bratislava. Retrieved February 2, 2018, from https://www.vub.sk/files/sekundarna-navigacia/financial-indicators/annualreports/vubannualreport02.pdf

VUB Bank (2005). 2005 VUB Annual Report (Annual report) (p. 106). Bratislava. Retrieved January 20, 2018, from http://www.vub.cz/vub/web.nsf/en/vyrocni_zpravy/\$FILE/ VUBannualreport05.pdf

VUB Bank (2006). 2006 VUB Annual Report (Annual report) (p. 104). Bratislava. Retrieved February 5, 2018, from http://www.vub.cz/vub/web.nsf/en/vyrocni_zpravy/\$FILE/ VUBannualreport06.pdf

VUB Bank (2008). 2008 VUB Annual Report (p. 153). Bratislava. Retrieved February 2, 2018, from http://www.vub.cz/vub/web.nsf/en/vyrocni_zpravy/\$file/vubannualreport08.pdf

VUB Bank (2017). History of VUB. Retrieved June 12, 2017, from https://www.vub.sk/en/ banks-profile/history-vub/\#tab_1

Yin, R. K. (2009). Case Study Research: Design and Methods (4th ed.). Thousand Oaks: SAGE Publications.

Yin, R. K. (2010). Analytic Generalization. In A. J. Mills, G. Durepos, \& E. Wiebe (Eds.), Encyclopedia of Case Study Research (pp. 21-23). Thousand Oaks: SAGE Publications.

\section{Author}

\section{Stefano Valdemarin}

$\mathrm{PhD}$ Researcher in International Business

University of Lyon, Jean-Moulin - iaelyon

Magellan Research Centre

Lyon, France

stefano.valdemarin@univ-lyon3.fr 